\title{
Protokół z Walnego Zgromadzenia Delegatów Polskiego Towarzystwa Filozoficznego $z$ dnia 13.02.2015 r.
}

DOI: http://dx.doi.org/10.12775/RF.2016.035

Profesor Barbara Markiewicz przywitała zebranych delegatów.

Zostały odczytane wspomnienia po zmarłych 2014 r. członków PTF.

Następnie jednomyślnie wybrano prof. Marka Rembierza na przewodniczącego Walnego Zgromadzenia Delegatów oraz dr Magdalenę Gawin na sekretarza Zgromadzenia.

Przyjęcie protokołu z poprzedniego Walnego Zgromadzenia Delegatów PTF:

protokół z poprzedniego Walnego Zgromadzenia PTF został przyjęty przy jednym głosie wstrzymującym się.

Sprawozdanie merytoryczne:

prof. Barbara Markiewicz przedstawiła sprawozdanie merytoryczne z działalności PTF w 2014 r. oraz z organizacji Olimpiady Filozoficznej, Międzynarodowej Olimpiady Filozoficznej i konkursu gimnazjalnego. Przy tej okazji prof. Markiewicz omówiła historię sporu z MEN oraz jego zakończenie.

Zgromadzeni zdecydowali, aby omówienie sprawozdania z działalności "Ruchu Filozoficznego", X Polskiego Zjazdu Filozoficznego oraz kwestii olimpiady dla gimnazjalistów nastąpiło po przyjęciu sprawozdań.

Sprawozdanie finansowe:

prof. Józef Stuchliński przedstawił sprawozdanie finansowe z działalności PTF za rok 2014 r. oraz zwrócił uwagę na brak sprawozdań z niektórych oddziałów. 


\section{Sprawozdanie Głównej Komisji Rewizyjnej:}

prof. Marcin Kubiak przedstawił sprawozdanie głównej Komisji Rewizyjnej wraz z wnioskiem o udzielenie absolutorium.

Po przedstawionych sprawozdaniach odbyła się krótka dyskusja, w trakcie której przedstawiono wniosek o podziękowania dla prof. B. Markiewicz, dr K. Wrzesińskiego oraz dr M. Gawin za zaangażowanie $\mathrm{w}$ rozwiązanie sporu $\mathrm{z}$ MEN.

Następnie odbyło się głosowanie nad wnioskiem Głównej Komisji Rewizyjnej oraz przyjęciem sprawozdań. Wniosek i sprawozdania zostały przyjęte przy dwóch głosach wstrzymujących się.

Prof. B. Markiewicz przedstawiła plan pracy PTF na rok $2015 \mathrm{r}$.

Plan został przyjęty przez zgromadzonych jednomyślnie.

\section{Sprawy członkowskie:}

przyjęto nowych członków PTF oraz podjęto kwestię problemu ze ściąganiem składek członkowskich.

\section{Sprawy różne:}

X Polski Zjazd Filozoficzny: prof. Krzysztof Brzechczyn przedstawił informację na temat kosztów udziału w Zjeździe oraz programu merytorycznego Zjazdu.

„Ruch Filozoficzny": prof. Marcin Zdrenka przedstawił sprawozdanie z działalności „Ruchu Filozoficznego”, poruszył także problem podniesienia punktacji. Prof. B. Markiewicz zaproponowała, aby przewodniczący oddziałów byli członkami rady redakcyjnej „Ruchu”. Prof. M. Kubiak wsparł ten pomysł wskazując, że taki zabieg przydaje się do parametryzacji. Z kolei prof. Brzechczyn zaznaczył, że ważne by było, aby włączenie się oddziałów PTF było aktywne. Dr Grzegorz Dominiak zwrócił uwagę, że być może nie każdy przewodniczący oddziałów byłby zainteresowany włączeniem się do prac związanych $\mathrm{z}$ „Ruchem”. Prof. Paweł Łuków zaproponował rozwiązanie kompromisowe polegające na tym, aby oddziały terenowe PTF delegowały osoby chętne do współpracy z „Ruchem”. Prof. M. Zdrenka zadeklarował otwartość na współpracę. Odbyło się głosowanie, w wyniku którego propozycja prof. P. Łukowa została przyjęta jednomyślnie.

Olimpiada dla gimnazjalistów: MEN zapowiedziało, że w przyszłym roku szkolnym zostanie ogłoszony konkurs na organizację olimpiad przedmiotowych dla gimnazjalistów. Możliwości i utrudnienia wystąpienia o organizację olimpiady filozoficznej dla gimnazjalistów przedstawiła prof. B. Markiewicz. Padło pytanie, czy PTF jest w stanie podołać organizacji kolejnej olimpiady. Zwrócono uwagę, 
jak trudnym zadaniem jest organizacja Olimpiady Filozoficznej dla szkół ponadgimnazjalnych. Dr M. Gawin przedstawiła argumenty na rzecz zaangażowania PTF, wynikające z doświadczeń z organizacji konkursu dla gimnazjalistów oraz z tego, że nauczyciele i uczniowie gimnazjum bardzo chętnie uczestniczą $w$ rozmaitych konkursach. L. Garcarz wsparł tę argumentację. Prof. M. Woźniczka zwrócił uwagę, że kluczem do sukcesu, a jest nim popularyzacja filozofii, jest edukacja szkolna. J. Czarnota stwierdził, że istotnym jest, aby dzielić się doświadczeniami i wiedzą z młodymi ludźmi. Prof. K. Brzechczyn poparł myśl, aby wspierać filozofowanie wśród młodych, dzięki czemu być może więcej osób wybierałoby w szkołach etykę jako przedmiot nauczania. W wyniku głosowania przyjęto uchwałę przy jednym głosie wstrzymującym się upoważniającą ZG PTF do udziału w konkursie na organizację olimpiady filozoficznej dla gimnazjalistów.

Prof. B. Markiewicz zaproponowała, aby powołać Radę Promocyjną Olimpiady Filozoficznej, której zadaniem byłoby promowanie uczestnictwa w OF np. poprzez popularyzację tematów etapu szkolnego itp. Walne Zgromadzenia uchwaliło zgodę na powołanie Rady przy jednym głosie wstrzymującym się.

Wolne wnioski: odbyła się krótka dyskusja dotycząca strony PTF, która została zaatakowana przez program hakerski. Dr M. Gawin wyjaśniła, że strona PTF zostanie wkrótce zmieniona na nowa, opartą na innym oprogramowaniu, dzięki czemu będzie mniej podatna na tego typu ataki.

Uroczyste zakończenie Walnego Zgromadzenia Delegatów PTF. 